\title{
USGS Research on Florida's Isolated Freshwater Wetlands
}

\section{Introduction}

The U.S. Geological Survey (USGS) has studied wetland hydrology and its effects on wetland health and ecology in Florida since the 1990s. USGS wetland studies in Florida and other parts of the Nation provide resource managers with tools to assess current conditions and regional trends in wetland resources.

Wetlands are a valuable natural and ecological resource in Florida and represent a greater percentage of the land surface than in any other state in the conterminous United States (Dahl, 2006). Wetlands covered an estimated 50 percent of the State before land-use changes and other human activities began to cause wetland losses in Florida (Dahl, 1990). In 1996, an estimated 11.4 million acres of wetlands remained, occupying 29 percent of the State. Freshwater wetlands make up 90 percent of the total wetland area Statewide, and coastal wetlands make up 10 percent. About 55 percent of the freshwater wetlands in Florida are forested, about 25 percent are marshes or emergent wetlands, 18 percent are shrub/scrub wetlands, and the remaining 2 percent are freshwater ponds (Dahl, 2005).

Wetland hydrologists in the USGS Florida Water Science Center (FLWSC) have completed a number of interdisciplinary studies assessing the hydrology, ecology, and water quality of wetlands. These studies have expanded the understanding of wetland hydrology, ecology, and related processes including: (1) the effects of cyclical changes in rainfall and the influence of evapotranspiration; (2) surface-water flow, infiltration, groundwater movement, and groundwater and surfacewater interactions; (3) the effects of water quality and soil type; (4) the unique biogeochemical components of wetlands required to maintain ecosystem functions; (5) the effects of land use and other human activities; (6) the influences of algae, plants, and invertebrates on environmental processes; and (7) the effects of seasonal variations in animal communities that inhabit or visit Florida wetlands and how wetland function responds to changes in the plant community.

\section{Advances in Understanding Wetland Hydrology and Ecology}

Freshwater wetlands of central Florida are relatively small, mostly isolated, and widely distributed (Haag and Lee, 2010) but are a dominant feature of the landscape, numbering in the thousands. The relatively small size and large number of freshwater wetlands present challenges for characterizing these wetlands collectively as a statewide water resource (Lee and Haag, 2006). Freshwater wetlands are distributed differently in central Florida than in other parts of the State. In the panhandle and in northern Florida, there are fewer isolated wetlands than in the central and southern parts of the State, and few of those wetlands are affected by activities such as groundwater withdrawals. In southern Florida, the vast wetlands of the Everglades and the Big Cypress Swamp blanket the landscape and form contiguous shallow expanses of water, which often exhibit slow but continuous flow toward the southwestern coast.

Comparing altered wetlands to natural wetlands in the same region improves the ability to interpret the gradual and cumulative effects of human populations on freshwater wetlands. Hydrologic differences require explicit attention because they affect nearly all wetland functions and are an overriding influence on other comparisons involving wetland water quality and ecology. Research conducted by FLWSC hydrologists resulted in several new approaches for quantifying wetland characteristics and evaluating the hydrology, water quality, and ecology of isolated freshwater marsh and cypress wetlands in the mantled karst terrain of central Florida (Lee and others, 2009). Key components of the research included the evaluation of

(1) the hydrogeologic framework of wetlands and wetland and groundwater interactions; (2) wetland water budgets, with a focus on the role of leakage and runoff; (3) the water quality of wetland surface waters and the geochemistry of 
underlying aquifers; (4) the frequency, duration, depth, and spatial extent of wetland flooding; and (5) assessments of periphyton communities, aquatic vegetation, and macroinvertebrate taxa richness and density.

Florida's wetlands are complex ecosystems that are increasingly important to residents. In many places, wetlands are flanked by uplands, generating a mosaic of contrasting environments - unique wildlife habitat often adjacent to dense human populations. As the population of Florida increases, the number of residents living near wetlands also increases. Living in close proximity to wetlands provides many Floridians with an increased awareness of nature and an opportunity to examine the relationship between people and wetlands. Specifically, these residents can observe how wetlands are affected by human activities. FLWSC hydrologists have conducted studies to address the need for a broader understanding of the interactions between wetland ecosystems, surface-water and groundwater resources, and human activities in Florida (Lee and others, 2009; Haag and Lee, 2010; Metz, 2011).

\section{USGS Wetland Research Capabilities}

\section{Wetland hydrologists in Florida design studies to:}

Compare the hydrology, water quality, and ecology of isolated wetlands that have different vegetation types and hydrologic settings.

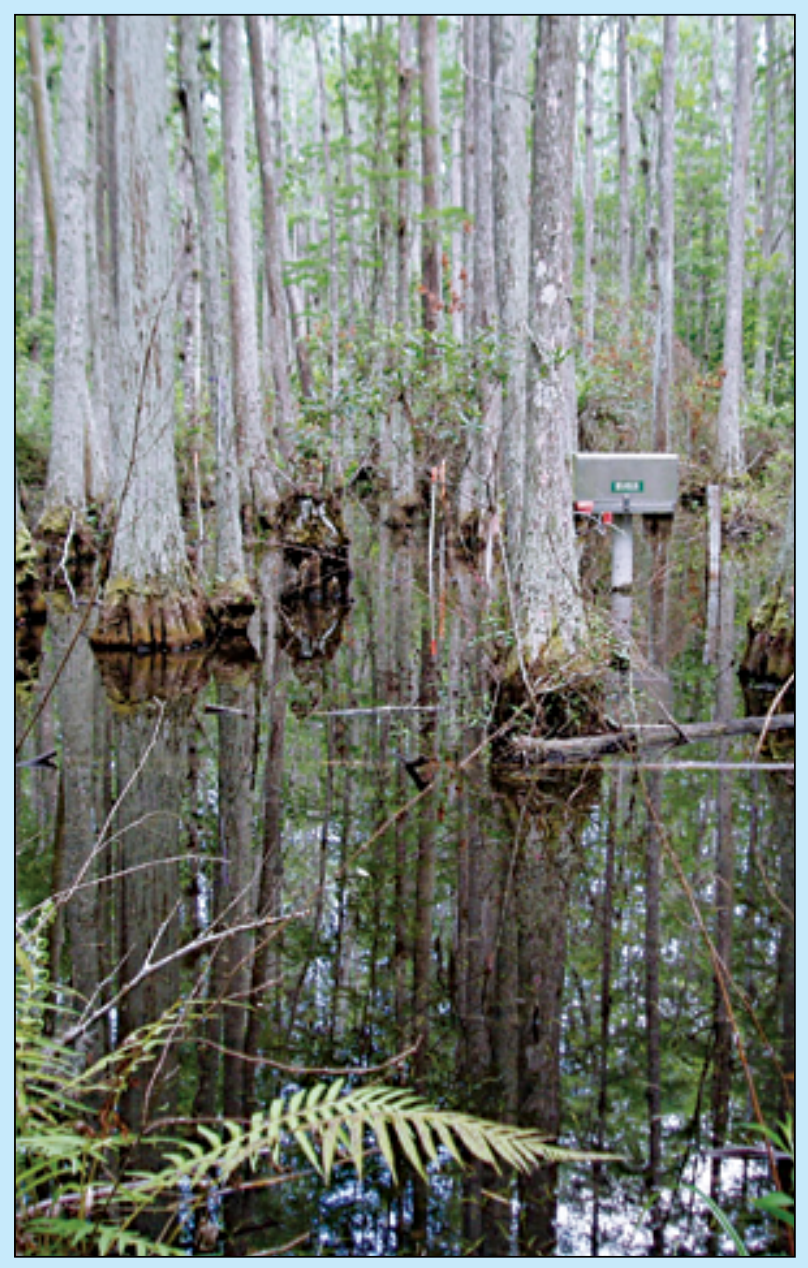

Use sediment coring, drilling, and geophysical surveying tools to describe the geologic framework of wetlands.

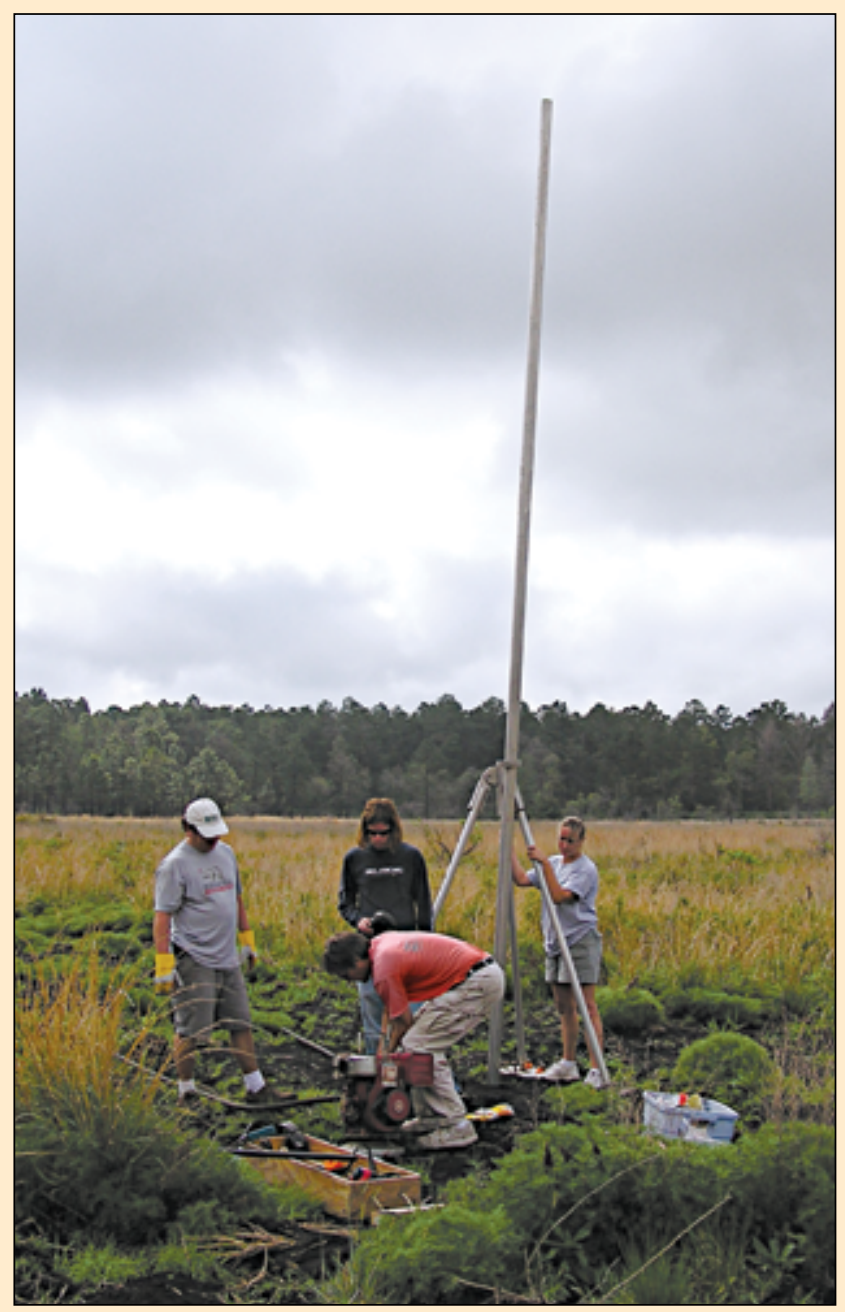

Describe the hydrogeologic setting of freshwater wetlands and quantify their groundwater interactions.

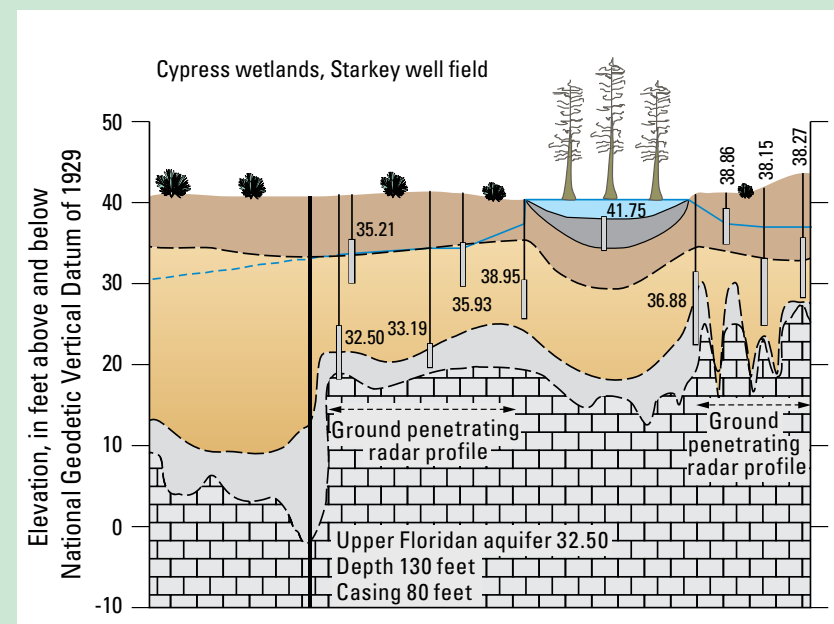


Study the effect of climate and groundwater withdrawals from well fields on wetland hydrology.

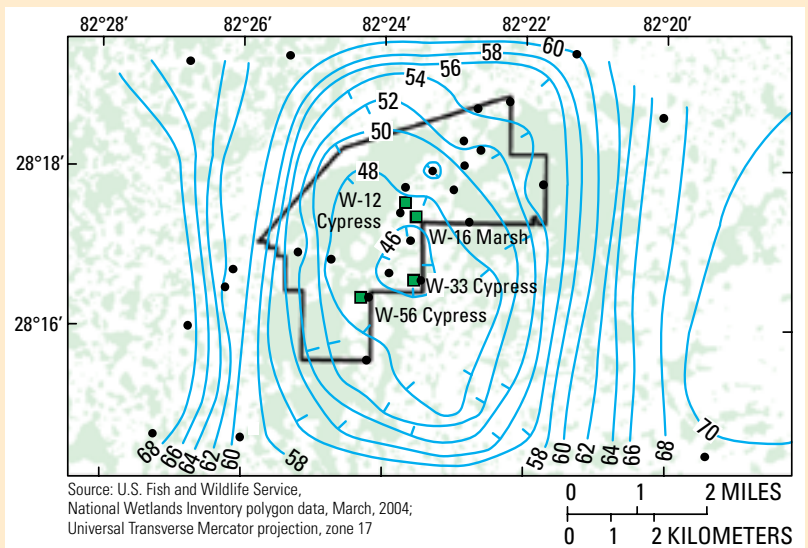

EXPLANATION

Well-field boundary

- 60 - Potentiometric contour - Shows altitude at which water would

have stood in tightly cased wells. Hachures indicate

depressions. Contour interval 2 feet. Datum is Nationa

Geodetic Vertical Datum of 1929

- Observation well

W-33 Cypress $\square$ Study wetland name and location

Map the bottom elevations of wetlands to relate wetland water levels to flooded area and plant zonation.

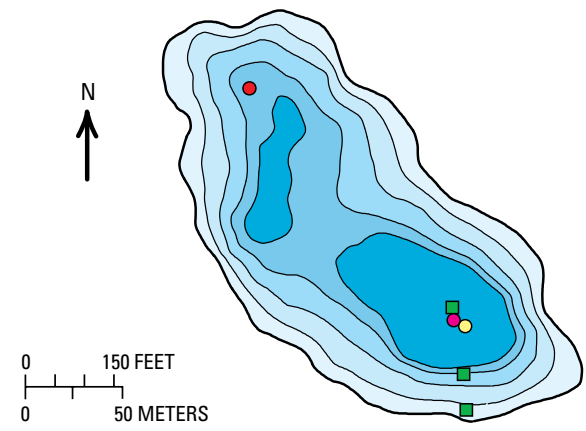

EXPLANATION

\section{Flooded area-In percent}

of total wetland area

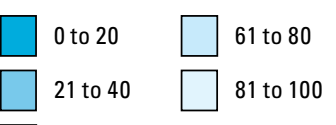

41 to 60

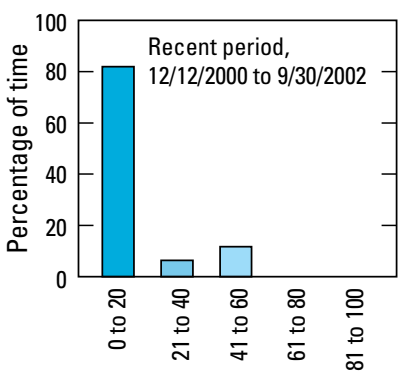

Percentage of total wetland area inundated
Define the relationship between standing water levels, flooded area, and flooded volumes in wetlands.

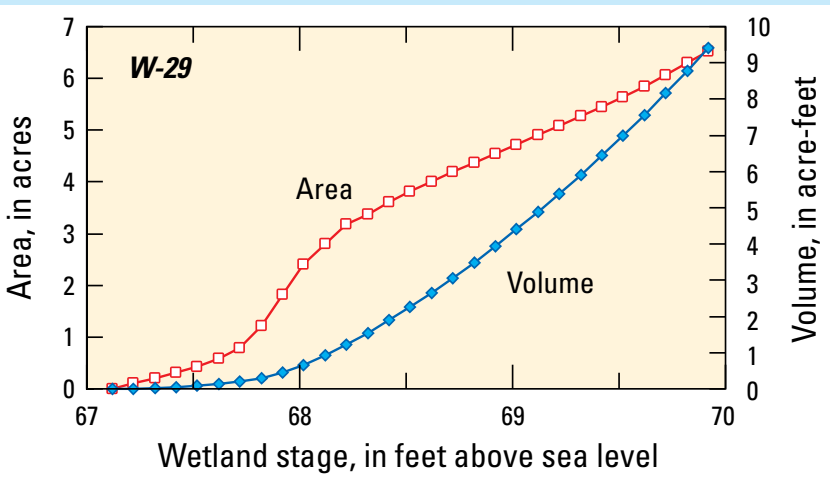

Compare flooding patterns in wetlands that are natural, impacted, and augmented with additional water to help evaluate the success of mitigation efforts.

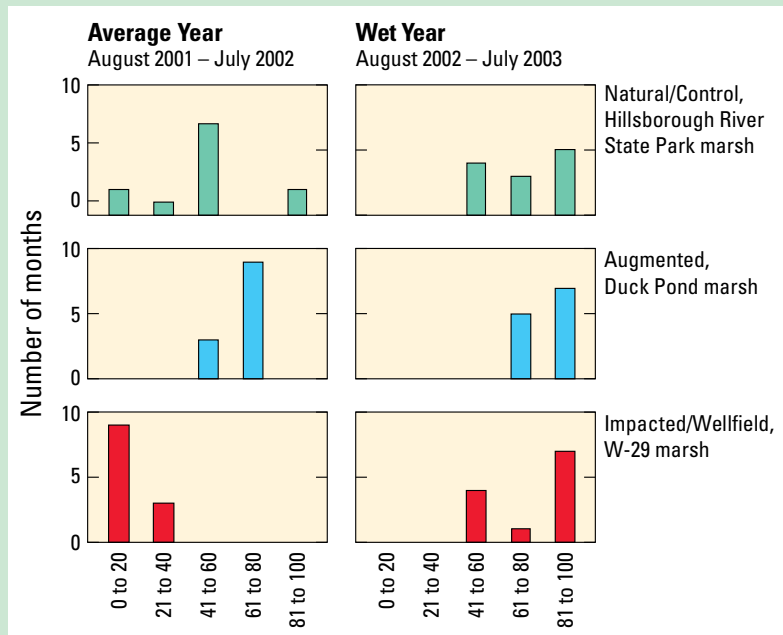

Percent of total area inundated

Monitor vegetation at different elevations in wetlands to relate flooding frequency and plant zonation.

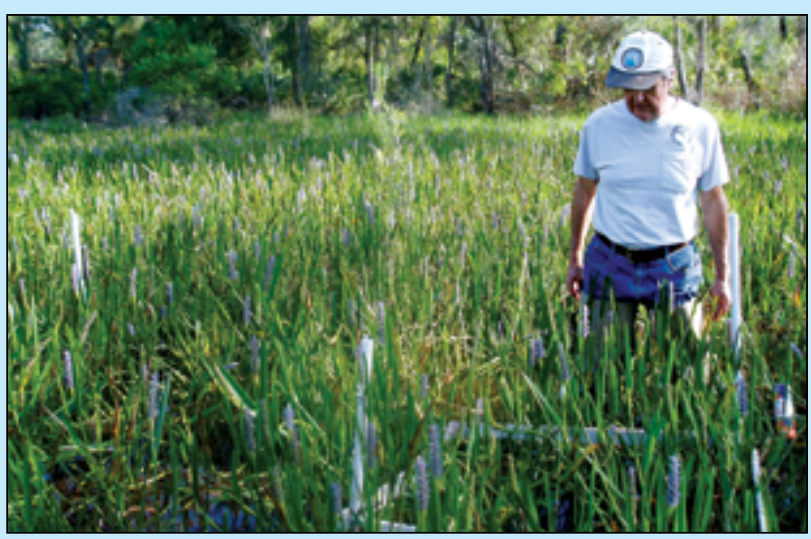


Conduct water-budget studies to quantify surface-water and groundwater fluxes in wetlands.

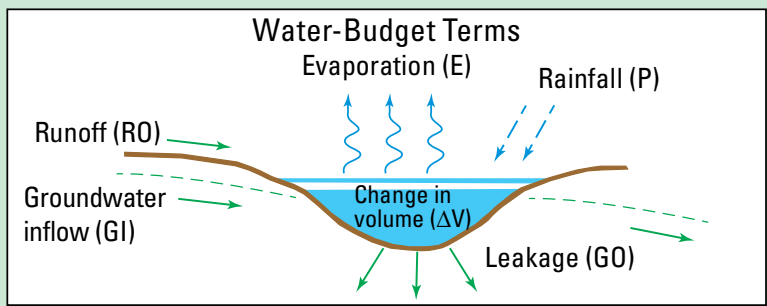

Rainfall and Wetland Stage
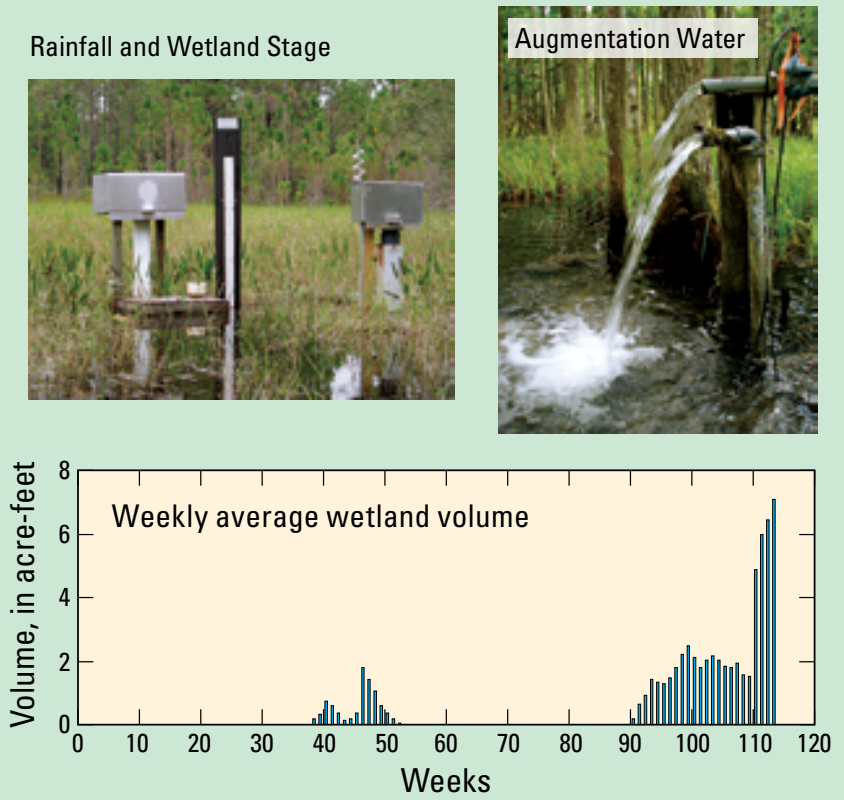

\section{Wetland Research Needs in Florida Include}

- Assessing the response of natural and altered wetland systems to climate change;

- Determining the effects of climate change on groundwater and surface-water interactions in freshwater and coastal wetlands;

- Characterizing wetland ecosystem structure, function, and critical processes affecting ecosystem sustainability and health;

- Characterizing and quantifying interactions between the physical, chemical, and biological components of wetland ecosystems;

- Determining how wetland ecosystems change in response to human activities; and

- Assessing recovery of wetland water levels as groundwater withdrawals from well fields are reduced.

\section{References for Additional Information}

German, E.R., 1996, A method for evaluating water-level response to hydrologic stresses in karstic wetlands in central Florida, using a simple water-balance model: U.S. Geological Survey Water-Resources Investigations Report 96-4216, 51 p.

Dahl, T.E., 1990, Wetland losses in the United States 1780s to 1980s: Washington, D.C., U.S. Fish and Wildlife Service report, 21 p.

Dahl, T.E., 2005, Florida's wetlands: An update on status and trends 1985 to 1996: Washington D.C., U.S. Fish and Wildlife Service report, 80 p.

Dahl, T.E., 2006, Status and trends of wetlands in the conterminous United States, 1998 to 2004: Washington D.C., U.S. Fish and Wildlife Service report, $80 \mathrm{p}$.

Darst, M.R., Light, H.M., 2008, Drier forest composition associated with hydrologic change in the Apalachicola River floodplain, Florida: U.S. Geological Survey Scientific Investigations Report 2008-5062, 81 p., plus 12 apps.

Haag, K.H., and Lee, T.M., 2006, Flooding frequency alters vegetation in isolated wetlands: U.S. Geological Survey Fact Sheet 2006-3117, 4 p., accessible at http://pubs.usgs.gov/fs/2006/3117/.

Haag, K.H., and Lee, T.M., 2010, Hydrology and ecology of freshwater wetlands in central Florida-A primer: U.S. Geological Survey Circular 1342, 138 p. (Also available at http://pubs.usgs.gov/circ/1342/.)

Haag, K.H., Lee, T.M., and Herndon, D.C., 2005, Bathymetry and vegetation in isolated marsh and cypress wetlands in the northern Tampa Bay area, 2000-2004: U.S. Geological Survey Scientific Investigations Report 2005-5109, 49 p. (Also available at http://pubs.usgs.gov/ sir/2005/5109/.)

Knowles, L., Jr., Phelps, G.G., Kinnaman, S.L., and German, E.R., 2005, Hydrologic response in karstic-ridge wetlands to rainfall and evapotranspiration, central Florida, 2001-2003: U.S. Geological Survey Scientific Investigations Report 2005-5178, 82 p.

Lee, T.M., and Haag, K.H., 2006, Strength in numbers: Describing the flooded area of isolated wetlands: U.S. Geological Survey Fact Sheet 2006-3118, 4 p. (Also available at http://pubs.usgs.gov/fS/2006/3118/.)

Lee, T.M., Haag, K.H., Metz, P.A., and Sacks, L.A., 2009, Comparative hydrology, water quality, and ecology of selected natural and augmented freshwater wetlands in west-central Florida: U.S. Geological Survey Professional Paper 1758, 152 p. (Also available at http://pubs.usgs.gov/ $p p / 1758 /$.

Light, H.M., Vincent, K.R., Darst, M.R., and Price, F.D., 2006, Water-level decline in the Apalachicola River, Florida, from 1954 to 2004, and effects on floodplain habitats: U.S. Geological Survey Scientific Investigations Report 2006-5173, 83 p., plus CD.

Merritt, M.L., 1992, Representing canals and seasonal inundated wetlands in a ground-water flow model of a surficial aquifer, in Jones, M.E., and Laenen, Antonius, eds., Interdisciplinary approaches in hydrology and hydrogeology: American Institute of Hydrology, p. 31-45.

Metz, P.A., 2011, Factors that influence the hydrologic recovery of wetlands in the Northern Tampa Bay area: U.S. Geological Survey Scientific Investigations Report 2011-5127, 58 p.

Schiffer, D.M., 1989, Effects of highway runoff on the quality of water and bed sediments of two wetlands in central Florida: U.S. Geological Survey Water-Resources Investigations Report 88-4200, 63 p.

\section{For more information contact:}

Arturo E. Torres (aetorres@usgs.gov) Kim H. Haag (khhaag@usgs.gov)
Terrie M. Lee (tmlee@usgs.gov)

Patricia A. Metz (pmetz@usgs.gov)
U.S. Geological Survey

Florida Water Science Center

(FLWSC-Tampa)

10500 Univ. Center Dr., Suite 215,

Tampa, Florida 33612 